\title{
worldview
}

\section{THE TEST-BAN TREATY AND CHARLES DE GAULLE}

Among the many nations that approved and signed the test ban treaty, two were conspicuous by their absence-China and France. While China's reasons seem evident, they have not been articulated with the precision and resonance that President de Gaulle brings to his public analyses of foreign policy issues. De Gaulle's recent series of speeches dealing with the role of France in world affairs takes full account of the possibilities that now lie before countries around the world and grandly asserts for France a position of leadership apart from the Soviets or "the Anglo Saxons." Although his words are sharp and discomfiting to other Western leaders, it cannot be denied that he continues to pose crucial questions and to place them in a long historical perspective.

In one of his press conferences de Gaulle said that "separate negotiations between the AngloSaxons and the Soviets, starting from the restricted nuclear test agreement, appear about to be extended to other questions, notably European questions, and so far in the absence of the Europeans. This evidently runs counter to the views of France. For a long time, France has believed that the day may conne when a sincere détente and even an entente will allow a complete change in the relations between East and West in Europe. When this day comes France expects to make constructive proposals concerning the peace, equilibrium and destiny of Europe."

More recently he has dismissed the UN as a "very useful forum"; accepted the Atlantic $\mathrm{Al}$ liance as a necessary organization, but an orgamization on which it is neither necessary nor desirable for France to depend for its defense; and acclaimed the European Economic Community if it did not deliver its member nations into a United Europe "without soul, without backbone and without roots" that would submit to the East or to the West. "The obligation to play our" own role, to allow nobody the right to act and to speak for us, marks our participation in the international enterprises of our epoch."

-

From de Gaulle these views are neither new nor surprising. They are consistent with his views of the proper role for France that irritated Churchill and Roosevelt. But now they are offered, indeed they are asserted, at a time when the post-war power structure is undergoing subterranean changes and the possibility and the need for strong, persuasive long-range policy along more fluid lines seems once again very possible.

The challenge posed to other Western leaders, notably the leaders of the United States, is that de Gaulle is keenly aware of the changes taking place, intent on having a leading voice in determining in what direction they will flow, imaginative enough to have definite plans, and stubbon enough to oppose and possibly frustrate those who do, not share his vision. And he speaks with an eye cocked to a wide audience, for he claims that France today offers an example to nations of the Soviet bloc, to South American countries, to the newer countries of Africa and Asia.

There is much to commend de Gaulle's logic and good reason to recognize his political ability. Nevertheless, if his views were to prevail it would represent a severe defeat for present American foreign policy. It is not only that de Gaulle treats lightly those institutions which the United States has vigorously supported-the UN, the Atlantic Alliance, the Common Market, etc. -nor that de Gaulle's policies, if successful, would make him the undeniable lcader of $\mathrm{E} t \mathrm{t}$ rope's policies; it is simply that major policies of the strongest nation in the West would be determined by a less strong nation. Like the judo expert, de Gaulle would take advantage of the 
greater strength of another to accomplish his own purposes. And the "other," whoever he is, ends up looking somewhat foolish.

Part of de Gaulle's own strength is his olympian attitude which, it is probably fortunate, no other world leader has; part of his strength derives from the inswerving faith in himself as the voice of France, the shaper of its destiny; but a large part is his ability to perceive and articulate real shifts in the relations between nations. His voice, more than any other in the Western world, called attention to the end of the postwar world, and in the recent series of intra-al. liance skirmishes he has won many rounds by default.

All this underlines the lack of an expressed U.S. foreign policy which acknowledges the changing political scene. Admittedly de Gaulle is bound by fewer restrictions and can be more spontaneous and free-wheeling than the high representatives of the United States. But the test-ban treaty, the Sino-Soviet dispute, the increasing pressure for East-West trade, and the Gaulist pronouncements all point to problems and opportunities that remain publicly unexplored in major discussions of U.S. foreign policy.

\section{in the magarines}

The editor of continutu, a new independent quarterly in Chicago, has taken a critical look at the "McNamara doctrine" of "counterforce plus avoidance" or "no-cities warfare" which the Defense Secretary set forth in his University of Michigm address last year and which a number of Christian moralists have championed as a moral breakthrough in our defense policics.

In the journal's sccond issue (Summer 1963), Justus George Lawler makes special reference to the writings of John Courtney Murray, S.J. and the pamphlet The Limits of Nuclear War by Paul Ram. sey, whose work he considers representative of the attempt "to make ethical sense of our present defense posture."

Lawler raises "pragmatic objections" to the possibility of "any rational limitation of war" in the nuclear age and states that "such moral theologians [as Ramsey and Murray] have hypostatized the no. tion of classical war, and rather than now modify the concept to $\mathrm{At}$ the facts, they are attempting with the best of will and with considerable ingentity to change the facts to conform to the abstraction. ... Nuclear war cannot now be war in any accepted sense of that word, and it has been recognition of this fact that has led strategists to adopt a policy of deterrence, which is the only military policy that can be effective in our times, however intrinsically inmoral it may be in itself."

"How, then, should the Christian citizen living in a nation which has publicly adopted the latter strategy conduct himself?" Lawler suggests "that his attitude toward the deterrent state qua deterrent state ought to be akin to that of the early Christians to. wards the Roman Empire. The deterrent is at pres- ent an instrument, however unstable, perilous, and immoral, for maintaining the present international condition of non-war, even as the Roman Empire was the instrumcut which allowed Christianity to diffuse itself throughout Europe and Asia. ... The overwhelming issue now concerns the drawing of what good one can from the possibly brief period of uncertain concord ahead. This will mean informing oneself and the community of the facts of nu. clear warfare and of their moral consequences; it will mean the advocacy of one or another technique for reducing tensions... and ... actively imple. menting the religious and social programs of Mater et Magistra and Pacem in Terris. The Christian citi$z e n$ in the deterrent state cannot afford to expend his energy on stcrile jeremiads-there is simply not enough time Ieft for that luxury."

$+$

The problems of structure and composition of a world force are considered by Mordecai Koshwald in the April edition of the Bulletin of the Atomic Scientists. The author is optimistic that many of the obstacles which seem to be in the path of ever realizing a truly international army can be ovcrome by "active measures" to instill "international loyalty," and a comprehensive plan of recruitment.

"One way to prevent a world army from turning into a world tyrant or a rebellious farce," Roshwald states, "can be provided by education, use of symbols, etc, that while inculcating loyalty to humanity also obstruct tyranny or rebelition."

Dismissing a world army of different nutional contingents under international command as prone to disintegration and political control, he would ad- 